\title{
ALGAL DYNAMICS OF RIVER PANDU IN RELATION TO AMBIENT ENVIRONMENT
}

\author{
Sunita Verma ${ }^{1 *}$, Divya Tiwari ${ }^{2}$ and Ajay Verma ${ }^{3}$ \\ ${ }^{1}$ Christ Church College, Kanpur - 208001, India \\ ${ }^{2}$ Department of Botany, ANDMM, Kanpur, India \\ ${ }^{3}$ Directorate of Wheat Research, Karnal, India \\ *Email: sunitaverma2k11@gmail.com
}

\begin{abstract}
An investigation on river Pandu in the year 2009-2010 was carried out to explore its current status in terms of physico-chemical and phycological profile. The study revealed that algal spectrum of the river was connected with the intensity of pollution in the river. River, at present is a perturbed ecosystem due to heavy anthropogenic stress on it. Despite abundant nutrients and other factors responsible for propping algal growth, river had a meak algal population and low diversity as compared to other perennial rivers indicating the grossly polluted unhealthy condition of the river. Algae are natural inhabitants of aquatic environment; and act as natural purifiers due to their nutrient gleaning and oxygenating capabilities; they are more sensitive than animals to industrial and municipal wastes. Maximum number of species existed at station- 1 followed by stations- 4 and 6 and then at station-5. Lowest species representation has been noticed at stations- 2 and 3 . Species number and algal population too declined sharply at stations- 2 and 3 as compared to station-I. Sharp decline in algal population at stations- 2 and 3 may be attributed to certain obvious reasons such as low transparency and reduced illumination as a consequence of residual fly ash discharged by PTPP drain at station-2. Except station-1, all downstream stations show grossly polluted condition of the river.
\end{abstract}

Key words: River Pandu, algal dynamics, physico-chemical profile, pollution.

\section{INTRODUCTION}

Algae, the natural inhabitants of any aquatic environment, play diverse roles in their habitats as natural purifiers, primary producers, ecological indicators (Walsh et al. 1980, Baruah and Das 2001). Periodicity and abundance of diverse algae in an aquatic ecosystem solely depends on the physico-chemical profile of the ambient water, available nutrients and substrata (Louis et al. 1967). Algal community, population, productivity and diversity together reflect the algal spectrum of any aquatic habitat which is chiefly controlled by certain physico-chemical factors. Any reasonable persistent change in the ambient environment is likely to cast its repercussions on the algal spectrum of the river. Algae usually show an inverse relationship with intensity of pollution and also reflect both long as well as short term critical events and conditions affecting them in between the consecutive samplings. Implication of algae in assessing the pollution and nutritional status of the river is well documented (Fjerdingstad 1964, 
Cholnoky 1968, Palmer 1969, Patrick 1973, Nygaard 1976). Phycological investigations are usually preferred over the cumbrous physicochemical investigation in assessing the pollutional status of aquatic habitats (Dwivedi 2010, Saikia et al. 2010, 2011 and 2012). The aim of the present study was to assess the current status of river in terms of its physico-chemical and phycological profile.

\section{MATERIALS AND METHODS}

River Pandu, a tributary of river Ganga, flows on the southern outskirt of the Kanpur city and receives huge quantity of industrial and municipal wastes of this big industrial, metropolitan city. Periodic investigations were made round the year but greater details could be worked out only during winter and summer because in monsoon period, survey and study got slightly hampered due to overflow and inapproachability of the river. The entire river stretch passing through Kanpur covering a length of about $60 \mathrm{~km}$ with 6 selected sampling stations was investigated. Since the river meanders though the interior of the city, it was not possible to select the sampling stations at equidistance from each other, through its desirability was realized. Due to inaccessibility of river, sampling stations could be selected only at those points where river reach was accessible, either via road or bridges.

The details of six sampling sites on River Pandu are as follows:

- Station 1: Upstream of confluence of Panki Power Plant Drain (PPPD)

- Station 2: Downstream approx. $0.25 \mathrm{~km}$ of confluence point

- Station 3: Downstream Panki municipal Drain

- Station 4: Approx. $30 \mathrm{~km}$ downstream station 3

- Station 5: Approx. $15 \mathrm{~km}$ downstream station 4

- Station 6: Approx. $30 \mathrm{~km}$ downstream station 5

10
Water and algal samples were periodically collected from these sites as per standard procedures. Samples were invariably collected from proper mixing zones. Random sampling was done at each station and the samples were then compounded to get a composite sample. Physicochemical analysis of the samples was done as per standard procedure (APHA 1998) and quantitative characterization of algae was done using pertinent literature on algae (Desikachary 1959, Smith 1950, Phillipose 1959, Tiffany and Britton 1952). Numerical strength of algae was done using Sedgewick Rafter Counting (S.R. Counting cell) repeatedly and results have been expressed as number of individuals per litre. Algal biodiversity was computed employing the information theory equation of Shannon and Weaver (1963) and Margalaf (1965). Degree of taxonomic similarity among the algal profile of different stations was computed using the equation of Sorenson (1948).

\section{RESULTS AND DISCUSSION}

The results pertaining to physico-chemical profile of the river water are depicted in Table 1.It is apparent from the data obtained that except transparency, dissolved oxygen and nitrate, the values of other parameter increased significantly at downstream stations. Water temperature increased downstream. Maximum temperature was recorded at station 2. Water was highly turbid at all downstream stations, but water transparency sharply declined at station 2 due to addition of ash slurry released into the river by Panki Thermal Power Plant (PTPP) drain. Transparency values reported at different stations showed pronounced periodic fluctuations. Transparency was lowest during monsoon, gradually increased in winter and then declined again in summer.

Addition of anthropogenic wastes especially municipal sewage via different drains into the river may be responsible for low DO and high BOD profile of the river. Discharge of sewage into the

ECOPRINT VOL 20, 2013 
river added huge amount of bio degradable wastes which exerted a negative pressure on the dissolved oxygen. This resulted in anoxygenic sag condition with a consequent increase in BOD values. BOD values were higher downstream as compared to upstream station 1.At times nil DO was reported at station 2 during extreme summer months, i.e., May and June. Water was alkaline all through the study period. In the present study hardness values ranged from $401 \mathrm{mg} / \mathrm{l}-1552 \mathrm{mg} / \mathrm{l}$ (Table 1). Hardness, though generally not regarded as pollution parameter and in natural waters it ranges from 10$500 \mathrm{mg} / \mathrm{l}$. Values above $500 \mathrm{mg} / \mathrm{l}$ relatively uncommon probably equilibrium maintained by water hardness. Low nitrate and high ammonia values reported at different stations were obviously due to oxygen-stressed condition of river water all along its entire stretch. Low DO availability hindered the natural bioconversion of ammonia into nitrate. Low values of transparency, DO, nitrate and high values of BOD, COD, ammonia all point to the inadequacy of oxygen for natural and complete biological oxidation of these pollutants. Data clearly revealed that river is under anthropogenic stress to an extent that it adversely affected its natural recuperating capability.

Phycological investigation of the river revealed 34 genera and 46 algal species in all from different stations (Table 2). Algal spectrum of the river at different stations lacked consistency of results, probably due to fluctuating quantity and quality of waste discharged into the river. Both plankton and periphytons have been reported but periphytons out-numbered the planktonic forms. The data pertaining to phycological investigations are depicted in (Tables 2-4). It is evident from the Table 3 that maximum number of species existed at station- 1 followed by stations- 4 and 6 and then at station-5. Lowest species representation has been noticed at stations- 2 and 3 . Out of a total 46 species, 8 have been reported exclusively from station-1 (Table 2) and have never been reported at any of the downstream stations. This insinuates that discharge of industrial and municipal wastes in the river downstream has disturbed algal community resulting in disappearance of more then $50 \%$ species at very next downstream station- 2 and also at station-3. At station-4 a few of them reappeared thus improving the number to 25 , which could not come at par to station-1 till station-6.

Table 3 depicts total algal individuals/ 1 and algal species number and diversity index values at each station. It is evident that not only the species number but algal population too declined sharply at stations- 2 and 3 as compared to station- 1 but at stations-4, 5 and 6 it increased considerably as compared to station-1. Sharp decline in algal population at stations- 2 and 3 may be attributed to certain obvious reasons such as low transparency and reduced illumination as a consequence of residual fly ash discharged by P.T.P.P. drain at station-2 and occasional discharge of coloured industrial wastes from Panki municipal drain upstream of station-3, and the presence of heavy metals in the water. These factors probably acted synergistically resulting in sharp decline in algal diversity as well as algal population (Ezra and Nwankwo 2001). Though sewage is also being discharged through these drains, but it seems that the growth stimulating effect of sewage on algal population is nullified by the toxic impact of heavy metals coupled with low transparency of water at these stations. As the river flowed downstream, toxicants got diluted in due course of time and further addition of sewage into the river through Khurja-nala/Halwa Kanda drain enriched the river with nutrients. Reduced toxicity, enhanced transparency and nutrient enriched river water enhanced the algal population at stations-4, 5 and 6 (Table 3) reaching a maximum of 339 individual at station-5. As compared to other perennial rivers, algal diversity as well as algal population in the river is quite low. 
Table 1. Physico-chemical profile of the Pandu river water.

\begin{tabular}{|c|c|c|c|c|c|c|c|c|c|c|c|c|}
\hline & \multicolumn{2}{|c|}{ S1 } & \multicolumn{2}{|c|}{ S2 } & \multicolumn{2}{|c|}{ S3 } & \multicolumn{2}{|c|}{ S4 } & \multicolumn{2}{|c|}{ S5 } & \multicolumn{2}{|c|}{ S6 } \\
\hline Parameters & Min & Max & Min & Max & Min & Max & Min & $\operatorname{Max}$ & Min & Max & Min & Max \\
\hline Temperature & 17.5 & 30 & 20.7 & 33 & 18 & 30.4 & 19.8 & 32.8 & 18.4 & 30.8 & 19.8 & 32 \\
\hline $\mathrm{pH}$ & 7.0 & 8.7 & 6.9 & 9.3 & 7.3 & 9.2 & 7.4 & 9.1 & 7.3 & 8.7 & 7.4 & 8.9 \\
\hline Total solids & 104 & 142 & 800 & 1200 & 300 & 900 & 500 & 1200 & 200 & 600 & 200 & 780 \\
\hline Transparency & 6.0 & 32 & 1.0 & 8.0 & 1.5 & 21 & 2.0 & 14 & 5.0 & 25 & 2.0 & 35 \\
\hline DO & 4.0 & 8.2 & 0.4 & 6.2 & 0.0 & 3.8 & 0.2 & 4.8 & 0.2 & 6.1 & 2.7 & 5.9 \\
\hline BOD & 10 & 36 & 10.8 & 50.6 & 16 & 80.6 & 10 & 111 & 10.8 & 80 & 10 & 60.2 \\
\hline COD & 12.6 & 27.4 & 95.0 & 543.6 & 39 & 495 & 42.6 & 327 & 38 & 269 & 39.8 & 183 \\
\hline Chloride & 7.1 & 47 & 25.8 & 134.8 & 7.7 & 158 & 18.9 & 122.5 & 15.7 & 92.7 & 17.3 & 73 \\
\hline Total Hardness & 440 & 1041 & 513.3 & 1238 & 456 & 1220 & 430 & 1552 & 527 & 997 & 401 & 900 \\
\hline Ammonia & 0.21 & 1.1 & 1.1 & 1.4 & 4.4 & 34 & $4 . .0$ & 10 & 8.0 & 12 & 0.5 & 6.0 \\
\hline Nitrate & 0.0 & 0.52 & 0.0 & 0.24 & 0.0 & 1.8 & 0.02 & 1.4 & 0.08 & 1.1 & 0.1 & 4.0 \\
\hline Phosphate & 0.17 & 0.38 & 0.27 & 4.32 & 0.25 & 4.75 & 0.28 & 4.76 & 0.24 & 4.12 & 0.25 & 3.45 \\
\hline Sulphate & 0.8 & 0.95 & 3.2 & 7.0 & 2.0 & 8.2 & 4.6 & 28 & 1.8 & 4.2 & 2.6 & 6.4 \\
\hline
\end{tabular}

All values in $\mathrm{mg} / \mathrm{L}$ except temperature ${ }^{\circ} \mathrm{C}, \mathrm{pH}$ and transparency

Table 2. Algal flora of the river Pandu at different stations.

\begin{tabular}{|c|c|c|c|c|c|c|}
\hline & Station 1 & Station 2 & Station 3 & Station 4 & Station 5 & Station 6 \\
\hline \multicolumn{7}{|l|}{ Cyanobacteria } \\
\hline Anacystis sp. & + & & & & & + \\
\hline Merismopedia minima & + & & & & & + \\
\hline Microcvstis sp, & & & & + & & + \\
\hline Nostoc sp. & + & & & & & \\
\hline Oscillatoria tenuis & & + & + & + & + & \\
\hline Oscillatoria limosa & & + & & + & & + \\
\hline Osciliatoria princeps & + & & & + & + & \\
\hline Oscillatoria sancta & + & & & + & + & + \\
\hline Oscillatoria curviceps & + & & & & & \\
\hline Phormidium tenue & + & + & + & + & + & \\
\hline Phormidium uncinatum & + & + & + & + & + & + \\
\hline \multicolumn{7}{|l|}{ Chlorophyceae } \\
\hline Actinastrum sp. & + & & + & + & + & + \\
\hline Ankistrodesmus sp. & & + & & + & + & \\
\hline Chlamvdomonas sp. & & & + & + & + & + \\
\hline Chlorella vulqaris & + & & & + & + & \\
\hline Cladophora qlomerata & & & + & + & + & \\
\hline Closterium sp. & + & & + & + & & \\
\hline Coelastrum sp. & + & & & & & \\
\hline Hydrodictvon reticulatum & + & & + & & & + \\
\hline
\end{tabular}


Pandorina morum

Pediastrum boryanum +

Pediastrum duplex +

Pediatrum simplex +

Pediastrum tetras

Scenedesmus guardicauda

Scenedesmus abundans

Spiroovra sp,

Stigeoclonium tenue

Zygnema sp

\section{Bacillariophyceae}

Achnanthes sp.

Asterionella formosa

Cyclotella sp.

Cymbella sp.

Diatoma elonqatum

Fraqilaria pinnata

Fraqilaria capucina

Melosira qranulatum

Navicula cryptocephala

Navicula cuspida

Nitzschia palea

Nitzschia acicularis

Pinnularia appendiculatum

Synedra sp.

Tabellaria floculosa

\section{Euglenophyceae}

Euglena sp.

Phacys sp.

Total sp

35

$+$

16

16

25

25

Table 3. Total algal individual $(n=12)$, species number and diversity index.

\begin{tabular}{|c|c|c|c|c|c|c|}
\hline & Station 1 & Station 2 & Station 3 & Station 4 & Station 5 & Station 6 \\
\hline No. of Individuals & 174 & 63 & 73 & 199 & 339 & 336 \\
\hline No.of Species & 35 & 16 & 16 & 25 & 22 & 25 \\
\hline Shannon - Weaver Index & 4.41 & 1.73 & 1.68 & 2.49 & 2.09 & 2.96 \\
\hline Margalef's Index & 3.96 & 1.06 & 1.19 & 2.08 & 1.44 & 1.93 \\
\hline
\end{tabular}

ECOPRINT VOL 20, 2013 
The degree of taxonomic similarity amongst the algal community of different stations is depicted in Table 4. Highest taxonomic similarity (0.73) existed between stations- 3 and 4 and then between stations- 4 and 5 (0.68). This indicates that somewhat similar conditions existed at the adjacent stations. Least taxonomic similarity (0.27) has been noticed between station-1 (unpolluted) and 2 (polluted).

Table 4. Co-efficient of algal similarity among different stations.

\begin{tabular}{ccccccc}
\hline Stations & S1 & S2 & S3 & S4 & S5 & S6 \\
\hline S1 & - & 0.27 & 0.39 & 0.5 & 0.44 & 0.66 \\
S2 & - & - & 0.63 & 0.63 & 0.58 & 0.41 \\
S3 & - & - & - & 0.73 & 0.63 & 0.51 \\
S4 & - & - & - & - & 0.68 & 0.54 \\
S5 & & - & & & - & 0.44 \\
\hline
\end{tabular}

Fig. 1 shows the periodic fluctuation in algal population at different stations. Lowest population at all stations has invariably been noticed in September, during monsoon but population peaks appeared in different months at different stations (Sadguru et al. 2002). At unpolluted or less polluted stations-1, 5 and 6 , maximum population has been noticed in summer (either May or June) while at grossly polluted stations-2, 3 and 4, population peaks appeared in winter (November/ December). The finding probably insinuates that in unpolluted or mildly polluted habitats, seasonal variation has a pronounced effect on algal population while in grossly polluted habitats its impact becomes secondary and algal growth, population and diversity is chiefly controlled by quality and quantity of the waste discharge into the habitat. Low algal population in September may be attributed to high water velocity, turbulence, turbidity and dilution due to rains. Ellis (1936) opined that silt acts as an opaque screen to light wavelengths, thus reducing photosynthesis and algal growth. But with the advent of summer, rise in temperature, low water velocity, abundant nutrients coupled with high light intensity-all stimulated algal population, which attained its peak in May (at stations-5 and 6) or June (station-1).

Cyanobacterial flora of the river is represented by only 6 genera and 11 species (Table 2). The maximum number of species ( $8 \mathrm{spp}$ ) has been noticed at station-1, followed by station-4 and then station-6, The frequently reported forms are Oscillatoria and Phormidium, Oscillatoria tenuis has been reported at downstream stations 2 to 5 while Anacystis spp and Merismooedia minima have been reported at only stations-1 and 6. Except station-1 Nostoc has not been reported at any of the downstream stations. This may be attributed to the fact that heterocystous forms usually do not inhabit in nitrogen rich water. Only Anacystis, Merismopedia and Microcystis are the plankton's representatives of this group.

Chlorophycean flora of the river is composed of only the members of Chlorococcales: Volvocales, Conjugales and Cladophorales. Only 13 genera and 18 species have been reported from different stations. Maximum diversity has been noticed at station-1 (14 species) while lowest (6 species) at station-2. The frequently reported forms are Chlamvdomonas sps, Chlorella vulgaris, Stigeodonium tenue and Pandorina morum offering their tolerance for organic and industrially polluted waters (Shaji and Patel 1991, Adhikari 1997, Baruah 1995, Jafari and Gunale 2006 and Saikia et al. 2010, 2012). The findings are in concordance with Palmer (1969) who enlists them as pollution tolerant algae. Pediastrum, the sole genus with maximum number of species has been reported only at stations- 1 and 6 while Coelastrum only at station-1. Stigeodonium tenue grew well at all the stations except station-5. Many investigators have reported the presence of Stigeodonium as an indicator of organic pollution. Tiwari et al. (1996) reported Stigeodonium tenue and Cladophora glomerata from Panki municipal drain that confluence with the river between stations- 2 and 3 . 
S-1

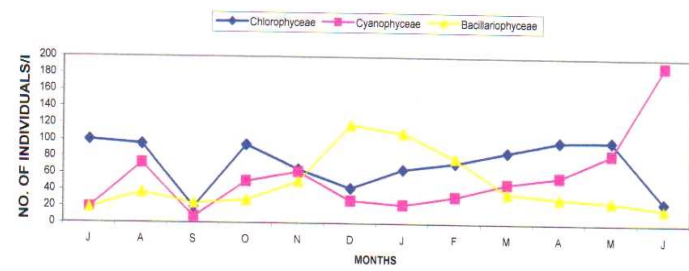

S-3

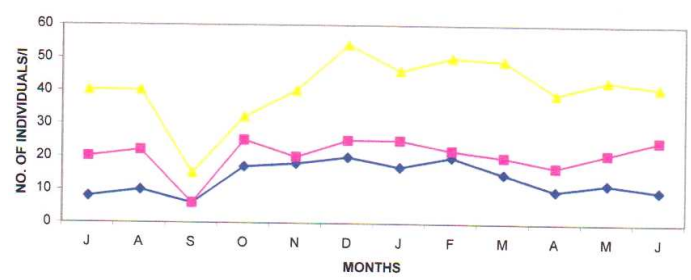

S-5

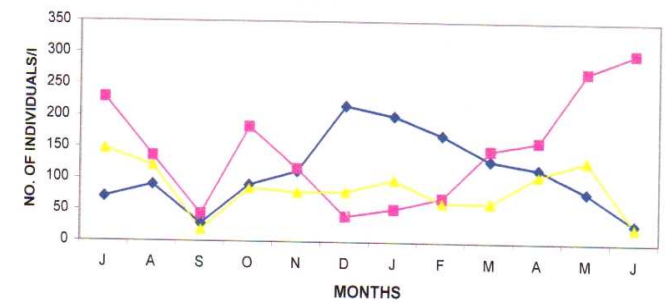

S-2

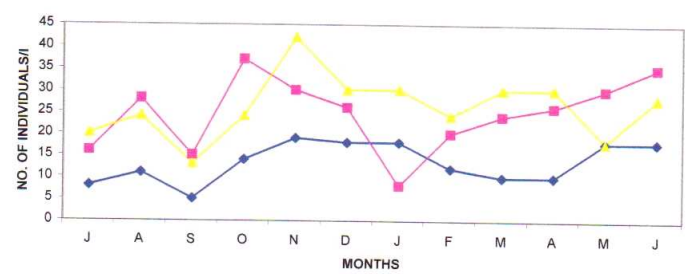

S-4

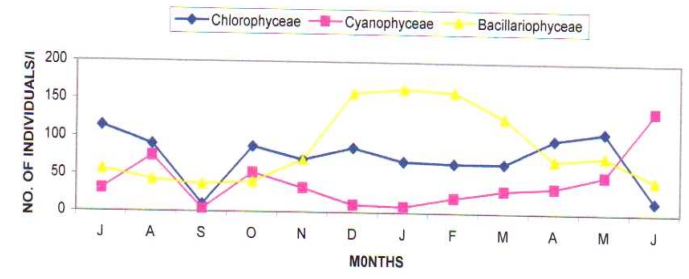

S-6

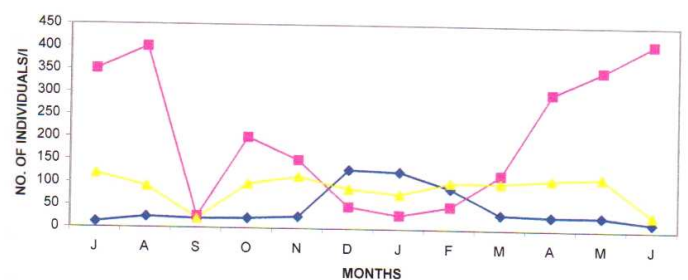

Fig. 1. The periodic fluctuation in algal population at different stations.

Abundant growth of Stigeoclonium has been associated with environments rich in heavy metals and nutrients. Industrial effluents that are being discharged into the river contain heavy metals and sewage-therefore presence of Stigeoclonium at these stations verifies the above finding. Presence of Cladophora glomerata at downstream stations-2 to 5 further affirms the presence of heavy metals in river water. Whitton (1979) stated that massive growth of Cladophora glomerata is indicative of the presence of heavy metals in low concentration. Cairns et al. (1972) too, reported Cladophora glomerata frequently in polluted water and tolerant to diverse degree of pollution. The present finding is in concordance with these observations.

Desmids are highly sensitive to pollution (Venkateswarlu 1981), and occasionally been reported at stations-1, 3, 4 and 5 and never at station-2. Van Oye (1934) pointed out that the paucity of desmids in Belgium waters was due to their eutrophic nature. Low number of desmids is an indication of high level of eutrophication in the river (Shaji and Patel 1991). Quite low number and occasional presence of desmids in the river indicates their sensitivity to pollution as well as the polluted nature of the river. Except Cladophora glomerata and Stigeoclonium tenue rest of the representative of this group are planktons.

Bacillariophycean flora of the river is composed of 12 genera and 15 species. Though generic as well as species representation of chlorophyceae out numbered the bacillariophyceae but so far their population is concerned, chlorophyceae lagged behind. Maximum bacillariophycean diversity (12 species) has been noticed at station- 1 followed by station- 6 ( 8 
species), stations-4 and 5 (7 species), station-2 (4 species) and then at station-3 (3 species). Achnanthes spp and Fraqilaria spp have been reported only at station-1 while Asterionella formosa, Cymbella spp and Diatoma elongatum only from stations-1 and 6. Navicula cryptocephala, Nitzschia palea, Melosira granulatum, Pinnularia appendiculatum, Synedra and Cyclotella spp at most of the stations. Except Achnanthes, Fraqilaria, Asterionella and Pinnularia, rest of the forms are well-documented pollution tolerant forms (Palmer 1969). Navicula cryptocephala and Nitzschia palea predominated the algal population at stations-2, 3 and 4 . Nitzschia palea tolerates oxygen stressed conditions and this may be the reason for its dominance at downstream-polluted station. Tiwari et al. (1996) too reported the presence of Nitzschia palea in Panki municipal drain that confluence with the river upstream of station-3. Butcher (1949) opined that in presence of high organic matter, water becomes polysaprobic and the most abundant and resistant forms in such habitats are diatoms such as Nitzschia palea and Gomphonema parvulum. The present study corroborates thesefindings.

The euglenophycean flora of the river is represented by only two genera Euglena and Phacus spp with meak population. Euglena has been reported only at stations- 2 and 5 while Phacus has invariably been reported from all the stations.

\section{ACKNOWLEDGMENT}

The authors are grateful to the Principal, Christ Church College, Kanpur for providing research facilities and to UGC, New Delhi for financial support.

\section{REFERENCES}

A.P.H.A. 1998. Standard methods for the examination of water and wastewater. American Public Health Association, Washington DC, USA.
Adhikari, S. 1997. Impact of Bongaigaon Refinery and Petrochemical Effluent on Algal Flora of Tunia River, Assam. Ph.D. Thesis, Gauhati University, Guwahati, India.

Baruah, B.K. and M. Das. 2001. Study on plankton as indicator and index of pollution in aquatic ecosystem receiving paper mill effluent. Ind. $J$. Env. Sci. 5(1):41-46.

Baruah, D.K. 1995. Studies on algae as biomonitors of pollution of some water bodies of greater Guwahati. Ph.D. Thesis, Gauhati University, Guwahati, India.

Butcher, R.W. 1949. Problems of distribution of sessile algae in running water. Vern. lnst. Ver. Limnol. 10:98-103.

Cairns, J. Jr., G.R. Lanza and B.C. Parker. 1972. Pollution related structural and functional changes in aquatic communities with emphasis on fresh water algae and protozoa. Proc. Acad. Natur. Sci. Phil. 124:79-127.

Cholnoky, B.J. 1968. Dieokologiederdiatomeen in Binnengewassern. J. Cramer. Lehrem. Germany 699.

Desikachary, T.V. 1959. Cyanophyta. Indian Council of Agricultural Research, New Delhi.

Diwedi, S. 2010. Pollution Induced Structural and Physico-Chemical Changes in Algal Community: A Case Study of River Pandu of North India. World Academy of Science, Engineering and Technology. 71:735-739

Ellis. M.M. 1936. Erosion silt as a factor in aquatic environments. Ecology 42:180-183.

Ezra, A.G. and D.I. Nwankwo. 2001. Composition of phytoplankton algae in Gubi Reservoir, Bauchi, Nigeria. Journal of Aquatic Sciences 16(2):115-118.

Fjerdingstad, E. 1964. Pollution of streams estimated by benthal phytomicroorganisms I. A saprobic system based on communities of organisms and ecological factors. Int. Rev. Geo. Hydrobip J. 49:63-131.

ECOPRINT VOL 20, 2013 
Jafari, N.G. and V.R. Gauale. 2006. Hydrobiological study of algae of an urban freshwater river. J. Appl. Sci. Environ. Mgt. 10(2):153-158.

Louis, A. De., W. Bock and N. Podoor. 1967. A floristic and ecological study of the plankton of five biotopes in the valley of the river Dyle, Belgium. Hydrobiologia 30:417-493.

Margalef, 1965. Information theory in ecology. Gen. Systems 3:36-71.

Nygaard, G. 1976. Tavlerne fra Dansk Planteclankton, Gylencendal 25.

Palmer C.M. 1969. A composite rating of algae tolerant organic pollution. J. Phycol. 5:78-82.

Patrick, R. 1973. Use of algae, especially diatoms, in the assessment of water quality. In: Special Technical Publication No. 528. A.S.T.M., Philadelphia, pp. 76-95.

Phillipose, M.T. 1967. Cholorococcales. Indian Council of Agriculture Research, New Delhi, India.

Sadguru, P., K. Khalid and K. Ansari. 2002. Seasonal dynamics of ptyto-zooplankton in fresh water pond developed from wasteland and brick kiln. Pollut Res. 21(1):81-83.

Saikia, M.K and P. Lohar. 2012. Structural and physicochemical correlation of algal community of a water body affected by pulp and paper mill effluents. Global Journal of Science Frontier Research 12(5).

Saikia, M.K., S. Kalita and G.C. Sarma. 2010. Algal indices to predict pulp and paper mill pollution load of Elenga Beel (wetland) Assam, India. Asian J. Exp. Biol. Sci. 1(4):815-821

Saikia, M.K., S. Kalita and G.C. Sarma. 2011. Growth stimulation (+) and inhibition (-) of algae treated to pulp and paper mill effluents. IJABPT 2(4):87-94.
Shaji, C. and R.J. Patel. 1991. Chemical and biological evaluation of pollution in the river Sabarmati at Ahmedabad, Gujrat. Phykos. 30:91-100.

Shannon, C.E. and W. Weaver. 1963. The Mathematical Theory of Communication. University of Illinois Press, Urbana, USA.

Smith, G.M. 1950.The Fresh Water Algae of United States. Pub. Mc.Graw-Hill Book Company, New York.

Sorenson, R. 1948. A method of establishing groups of equal amplitude in plant sociology based on similarity of species content and its application to analysis of vegetation on Danish Commons. K. Vid. Selsk. Biol. Skr. 5:1-35.

Tiffany. L.H. and M.E. Britton. 1952. The Algae of Illinois. The University of Chicago Press, Chicago, USA.

Tiwari, D., P. Kaur and S. Singh. 1996. Phycology of polluted drain. Geobios 23:197-202.

Van Oye, P. 1934. Quelques donnees sur 1 ' $e$ ' cologie des Desmidiees (English Summary). BuN. Soc. Roy. Bot. Belg. 67(Q):65-75.

Venkateswarlu, V. 1981. Algae as indicators or river water quality and pollution. In: $W H O$ Workshop on Biological Indicators and Indices of Environmental Pollution, Osmania University, Hyderabad, pp. 93-100.

Walsh, G.E. and S.V. Alexander. 1980. A marine algal bioassay method. Results with pesticides and industrial wastes. Water, Air and Soil. Pollut. 13:45-55.

Whitton, B.A. 1979. Algae and higher plants as indicators of river pollution. In: Biological Indicators of Water Quality . (eds.) James, A. and L. Evision. John Wiley and Sons, New York, pp. 5-34. 